\section{P - 417 Assay of sperm acrosin activity and its clinical application: contrast of activity in testis, epididymis and analysis of human sperm acrosin and its affecting factors} Bethune University of Medical Science.

Zhong-Wen Zhao and Chun-Hua Xiao

We have discovered a new method to detect the activity of human sperm. By this method we have detected 3 different fertile men. The result suggests that acrosin activity is related with the fertility. We collected testis and epididymis specimen from fertile men for assaying sperm density and acrosin activity of sperm in testis, epididymal capus, courpus and cauda. The result showed that there were no obvious difference for the acrosin in epididymal capus, corpus and cauda. We collected more than 300 semen samples of male infertility to assay the acrosin activity and most indices of sperm, ureaplasma urealyticum and antibody for sperm. It to the motility rate and the viability was inversely proportional to WBC count and the deformity rate. The acrosin activity was significantly related with the ureaplasma urealyticum infection while not related with the sperm antibody.
Dept. of Urology, First Teaching Hospital Of Norman showed that the acrosin activity was positively proportional P -418 前々LLeydig cell におけるNitric oxide の産

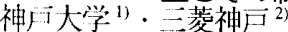

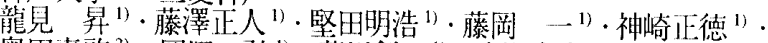

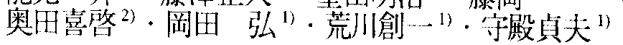

【目的】 Nitric oxide (NO) は NO synthase (NOS) により L arginine から生成されるフリーラジカルであり、様々な臓器 で重要な働きをしている。精紧においても NOが steroidogenesis を抑制することが報告されており、重要な役割 を担っていると考えられる。我々は㭃若扔よび成熟ラット Leydig cell 培養系を用い、NOの産生とその制御について検討 したので報告する

【方法】Leydig cell は幼若 (20日齢) および成熟 (8 週齢) ラ ットよりコラゲナーゼ処理にて分離し、無血清培地 (DMEM/F12)にて培養した。(1) 48 時間後、本培養系にIL$1 \beta(0.01-100 \mathrm{ng} / \mathrm{ml})$ 、TNF $\alpha(0.01-100 \mathrm{ng} / \mathrm{ml})$, for skolin $(0.01-$ $100 \mu \mathrm{M})$ 、または hOG $(0.01-100 \mathrm{ng} / \mathrm{ml})$ 老添加した。NOはGriess 法にて測定し、iNOS mRNA の発現は Northern blot 法にて定量 的に評価した。(2) ABC 法を用いて免没組織学的に iNOS の発 現を検傠した。(3) Pachytene spermatocyte (PS) および round spermatid (RSd) は、12 週龄ラットよりコラゲナーゼ処理の後、 Elutriationにて採取し、無血清培地(DMEM/F12)にて16時間培 養した。その上清を Leydig cell に添加し、同様にiNOS mRNA の発現量を検討した。

【結果】(1)Leydig cell の培養液中のNO 量は、IL-1 $\beta$ の添加濃 度依存性に増加し、NOS の阻害剂である1-NMMAによって抑 制された。TNF $\alpha$ 、forskolin、hCG の添加では NO 量に変化 は見られなかった。 iNOS mRNAの発現は、IL-1 $10 \mathrm{ng} / \mathrm{ml}$ の範囲で濃度依存性に增加し、6 時間の刺激で最高値 に達し、24時間までほほ持続した。(2) Rabbit anti-iNOS polyclonal 抗体を用いた免疫染色にて、Leydig cell の細胞質内 に iNOS 蛋白の発現が認められた。(3) PS、RSd の培養上清を Leydig cell に添加したものでは、双方ともIL-1 $\beta$ で刺激された Leydig cell $中 \sigma$ iNOS mRNA $の$ 発現を抑制した

【結論】Leydig cell の細胞質内に iNOS が存在しており、NO を産生していることか明らかになった。今後、さらに精巣に おける iNOSおよびNOの機能的役割を検剑卞ることにより、

精子形成の調節機構解明の采口になりうるものと考之られた。

P -419 精了卵結合の異常症例に㧍ける補体制御因子 大阪大学 ${ }^{11}$ 、大阪府立成人病七ンター研究所第 6 部 ${ }^{21}$ 北村雅哉1)、山中幹基 ${ }^{11}$ 、古賀実 ${ }^{1)}$ 、达村晃 ${ }^{1)}$ 、西村憲 ${ }^{-1)}$ 、 内田欽也 ${ }^{11}$ 、松宮清美 ${ }^{11}$ 、瀨谷司 ${ }^{21}$ 、奥山明彦 ${ }^{11}$

【目的】所謂不娃カップルのうち約10\%が男性要因、女性要因 とも通常の検查では異常か認められず、原因不明の不娃症とされ ている。これらの中に精子卵結合の異常による不娃症があるので はないかと考元、抗OD抗体を用いてスクリーニングを行った。 CD46 (Membrane Cofactor Protein ; MCP)は精子においてはinner acrosomal membraneに発現しており、精子卵結合に重要な役割を していると考元られている。【対象、方法】当科不奸外来に受診 した患者5Q名のうち、精夜所見が正常であり、女性側の要因も 否定され、AHまたはIVFを繰り返し試みるも娃娠に至らない、原 因不明の不妊カップル、63組を対像とした。【結果】 Acrobeads testは抗の16抗体を用いて精子の卵との結合能を見るもので、前 述の63症例の精子を検査したところ、7例㤬全〈凝集が見られな かった。次にこの例に対して4つの異なるエピトープをもつモノ タローナル抗体を用いて immuno-blottingを行ったところ、うち2 症例はどの抗体とも全く反応せず、1症例は一つの抗体とのみ反 応した。な扮、これらの異常症例に执いても白血球上には正常の の16か認められた。考察】これらのエピトープの認識部位が の46の細胞外ドメインの基質結合部位であるところから、精子の CD16の量的、あるいは質的異常はその卵結合能に影響寸るものと 思われる。これらの異常の原因として精子特異的なCD46遗伝子の 異常のほが精子特異的なpost-translational modificationの異常も考 えられ、他の補体制御因子についての検索もおこなう予定である。

\section{$\mathrm{P}-420$ 精子特異抗原HSAg-13およびHSAg-33 の免疫電影的検討}

宇治德洲会病院1) . 滋賀(科大学2) . 同解剖学第一3)

上仁数義1) 德永義光 ${ }^{3)}$. 吉貴達寛 ${ }^{2}$

Gregory Lee ${ }^{4)}$. 友吉唯夫 ${ }^{2}$

精子には、いまだ解析されていない未知の抗原が多数存 在しているのではないかと推測される。われわれは、精 子に特異性の高いマウス単クローン抗体を作製し、精子 形成過程における対応抗原の発現について検討し報告し てきた。(日泌総会，1996)【対象と方法】今回は健常男 性から得た新鮮精子を免疫原とするマウス単クローン抗 体HS-13(IgG1，抗原HSAg-13:80kDa，Proc 10th Ann Meeting JSIR, 35-36, 1996)およびHS-33(IgG1, 抗原HSAg$33: 72 \mathrm{kDa}, \mathbf{J}$ Androl. in press)を一次抗体として用いて、 SD系成熟ラット（潅流固定）およびヒト精巣（浸漬固 定）をABC法で免疫染色した。免疫染色後 $1 \%$ osumium で固定、脱水、樹脂包埋の後、2\% uranyl acetateおよび Reynolds`solutionで電子染色を行い透過電子顕微鏡で観 察した。【結果】ラットおよびヒトにおいて各々の抗体 は減数分裂後の精子細胞および精子に反応しており、他 の精单構成細胞はすべて陰性であった。反応部位は精子 細胞および成熟精子のそれぞれの先体部分でHS-13、HS33ともにintra-acrosomal regionに認められた。【結語】 マウス単クローン抗体HS-13, HS-33がそれぞれ認識する 抗原HSAg-13、HSAg-33は減数分裂後の精子細胞および 精子のintra-acrosomal regionに発現していると考えられ た。
ブリティシュコロンビア大学アンドロロジー研究室4) 